\title{
Pelvic Aneurysmal Bone Cyst in an Adolescent: A Case Report and Literature Review
}

\author{
Hadeel H. Alalawi ${ }^{1}$, Shoog Alfadhel ${ }^{2}$, Mahbub Khan ${ }^{3}$, Abdulrahman Bobseit ${ }^{3}$ \\ 1. Department of Orthopedics, King Fahad General Hospital, Madinah, SAU 2. Orthopedics, College of Medicine, King \\ Saud Bin Abdulaziz University for Health Science, Riyadh, SAU 3. Department of Orthopedics, Prince Sultan Military \\ Medical City, Riyadh, SAU
}

Corresponding author: Hadeel H. Alalawi, hadeel-422@hotmail.com

\begin{abstract}
An aneurysmal bone cyst $(\mathrm{ABC})$ is a benign but locally aggressive lesion. The challenge in managing pelvic $\mathrm{ABC}$ arises from its relative inaccessibility and the presence of nearby neurovascular structures. In this report, we present the case of a 14-year-old female with pelvic $\mathrm{ABC}$ and describe the symptoms, signs, and radiographic appearance of the $\mathrm{ABC}$, management, and good outcome of non-surgical management by selective trans-arterial embolization. Although challenging, non-surgical management of pelvic ABCs can result in a favorable outcome. In addition, we reviewed the literature regarding the treatment modalities of pelvic ABCs.
\end{abstract}

Categories: Orthopedics

Keywords: aneurysmal bone cyst, selective trans-arterial embolization, pelvis, benign

\section{Introduction}

An aneurysmal bone cyst $(\mathrm{ABC})$ is a rare benign, reactive, locally aggressive, and highly vascular tumor of unknown origin. It is an intraosseous and rare soft tissue lesion. It accounts for about one percent of benign bone tumors [1]. ABC can be a secondary to giant cell tumor, chondroblastoma, osteoblastoma, and osteosarcoma in $30 \%$ of cases [2]. In $52 \%$ of the cases, ABCs are found in the long bone metaphysis, as well as the sternum and spinal column [3].

$\mathrm{ABC}$ also occurs in the pelvis (8\%-12\%) [4]. Several factors make the management of pelvic ABC challenging, including difficulty in approaching the lesions, difficulty in achieving intraoperative hemostasis, nearby neurovascular bundles, and risk of injury to the acetabulum or sacroiliac joint that may affect the pelvic stability. Herein, we present a case of pelvic $A B C$, which treated successfully without complications via selective trans-arterial embolization (STAE).

Received 07/14/2020

Review began 07/18/2020 Review ended 07/18/2020 Published 08/03/2020

() Copyright 2020 Alalawi et al. This is an open access article distributed under the terms of the Creative Commons Attribution License CC-BY 4.0., which permits unrestricted use, distribution, and reproduction in any medium, provided the original author and source are credited.

\section{Case Presentation}

A 14-year-old female patient, without remarkable medical conditions, presented to the clinic with left hip pain for one year. The pain was progressive and not relieved by medications. She was limping with no history of constitutional symptoms. Physical examination findings revealed antalgic gait and limited range of motion due to the pain with mild swelling.

The pelvic radiographs showed an expansile osteolytic lesion involving the left superior pubic ramus and reaching to the left acetabulum anterior wall (Figure 1). Pelvic magnetic resonance imaging (MRI) showed fluid-fluid levels compatible with an aneurysmal bone cyst (ABC) (Figure 2). Tumor workup was done. Computed tomography-guided biopsy and histology revealed an ABC. 


\section{Cureus}

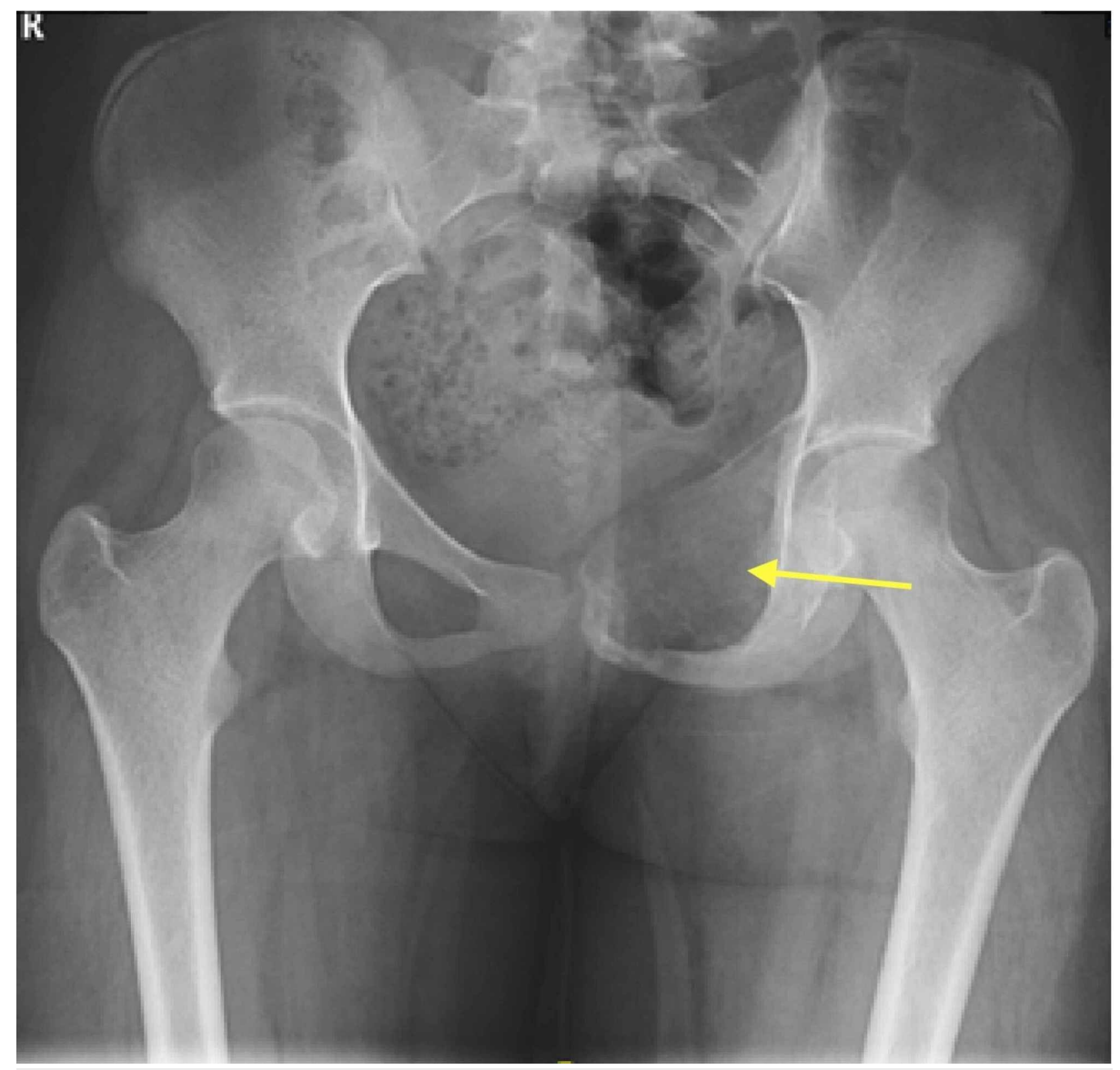

\section{FIGURE 1: Anteroposterior radiograph of the pelvis}

Showing an expansile osteolytic lesion involving the left superior pubic ramus and extending to the anterior wall of the left acetabulum. 


\section{Cureus}

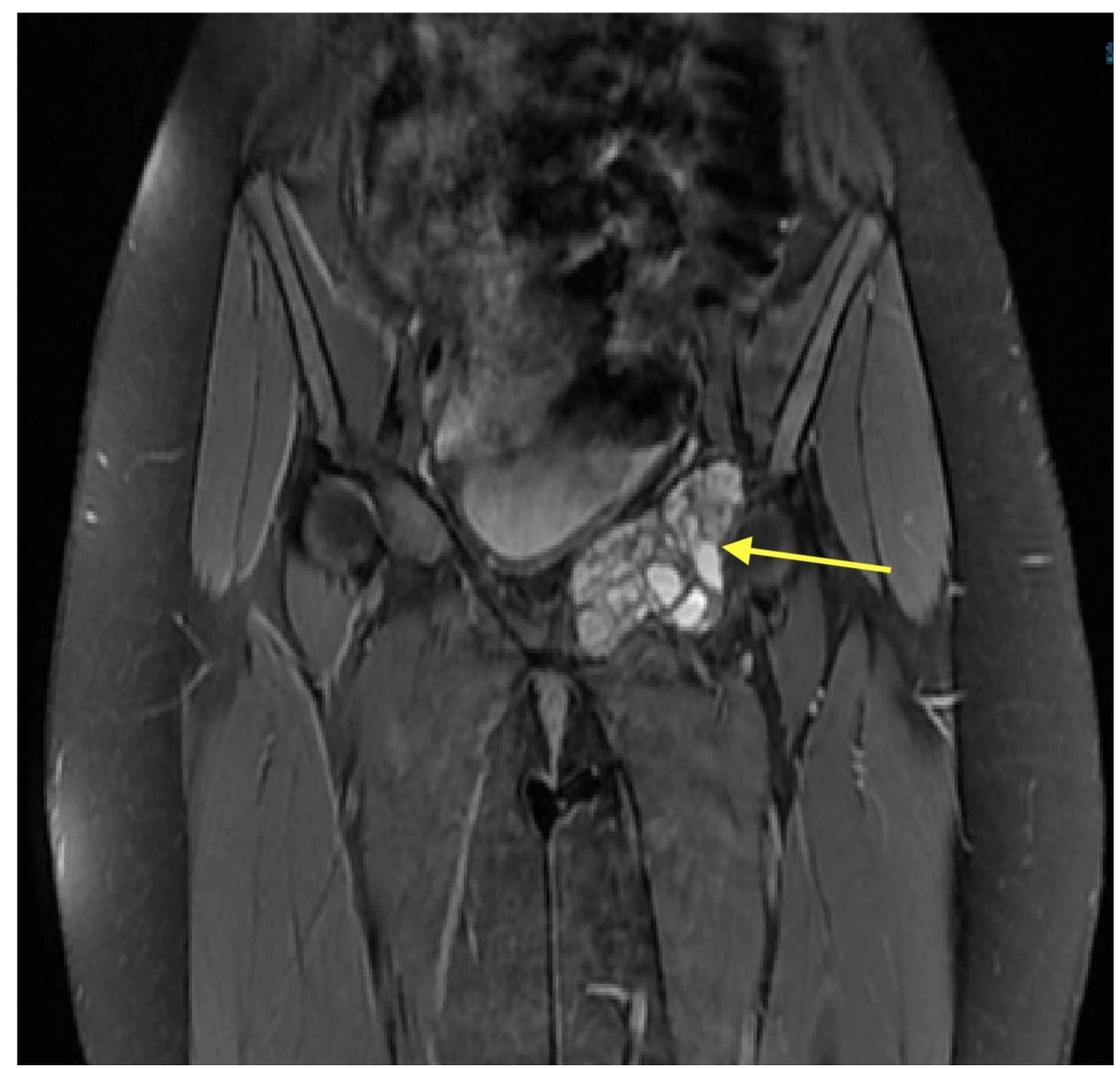

\section{FIGURE 2: T2-weighted magnetic resonance image}

Coronal view showed $6 \times 4.5 \times 3.5 \mathrm{~cm}$ well-defined lesion and demonstrated internal septations forming cysts containing fluid-like signal intensity.

The prognosis and treatment were discussed with the patient's parent. Her parent consented for STAE. Under local anesthesia, angiography and selective arterial embolization were carried out via the left common femoral artery. Two feeding arteries were identified that originating from the inferior epigastric and circumflex arteries. The feeding vessels were selectively catheterized using a 5-French diagnostic catheter and a microcatheter. Embolic agent polyvinyl alcohol (PVA) was injected successfully. Thereafter, angiography through the internal iliac artery anterior division demonstrated complete and successful embolization of the arterial supply to the lesion. On the next day, the patient has discharged home pain-free and allowed full weight-bearing.

The patient had a routine follow-up evaluation every three months initially and at six months thereafter. Follow-up routine evaluation included radiographs of the pelvis and left hip joint. Radiographs revealed progressive trabecular bone formation and a gradual reduction of the size of the lesion (Figure 3). At four year follow-up, she was symptom-free and able to walk without limping. MRI showed a reduction in the size as well as a cystic appearance with no local recurrence (Figure 4). 


\section{Cureus}

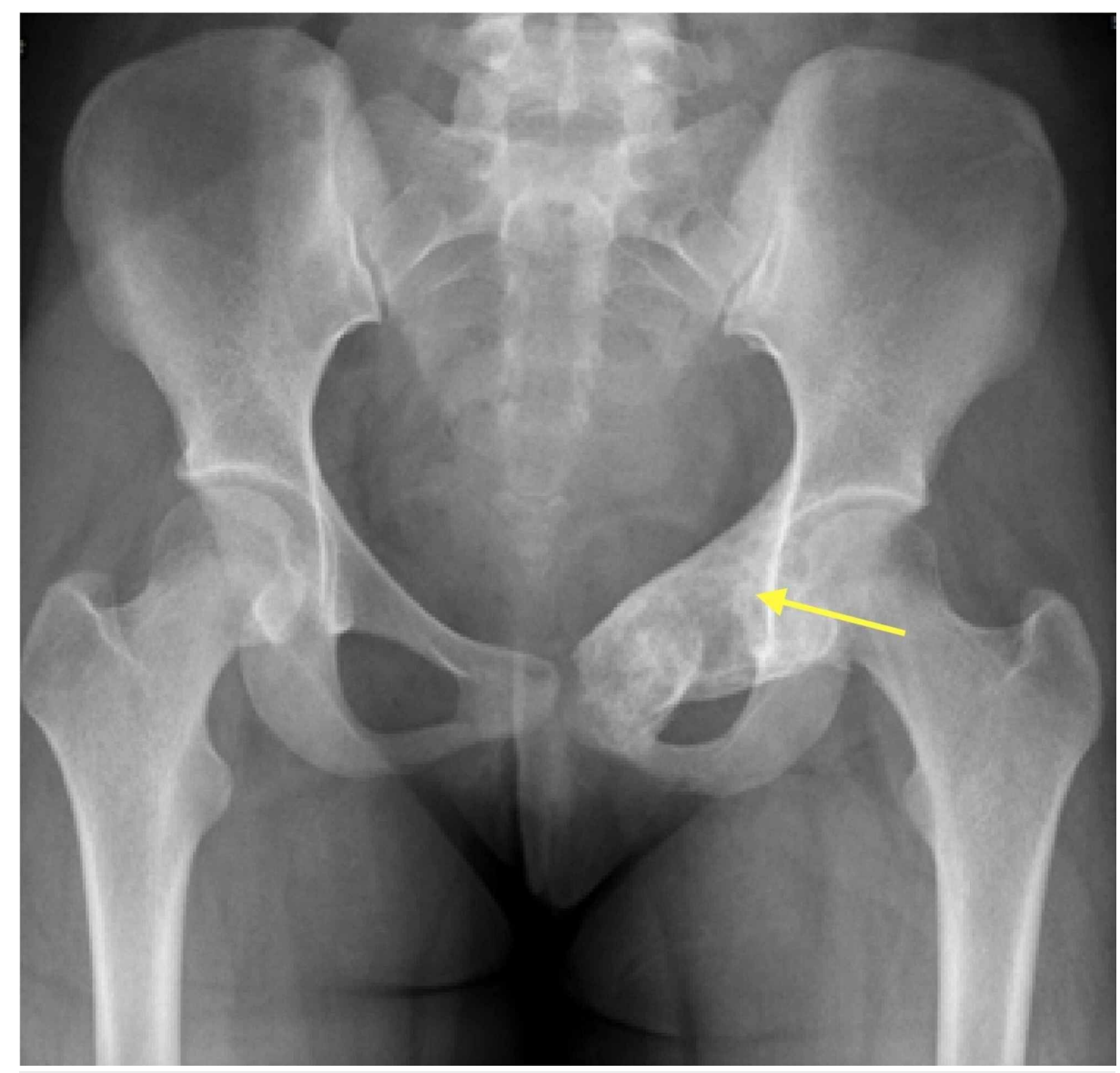

FIGURE 3: Anteroposterior radiograph of the pelvis four years post embolization

Showing homogenous trabecular bone formation and ossification of the lesion. 


\section{Cureus}

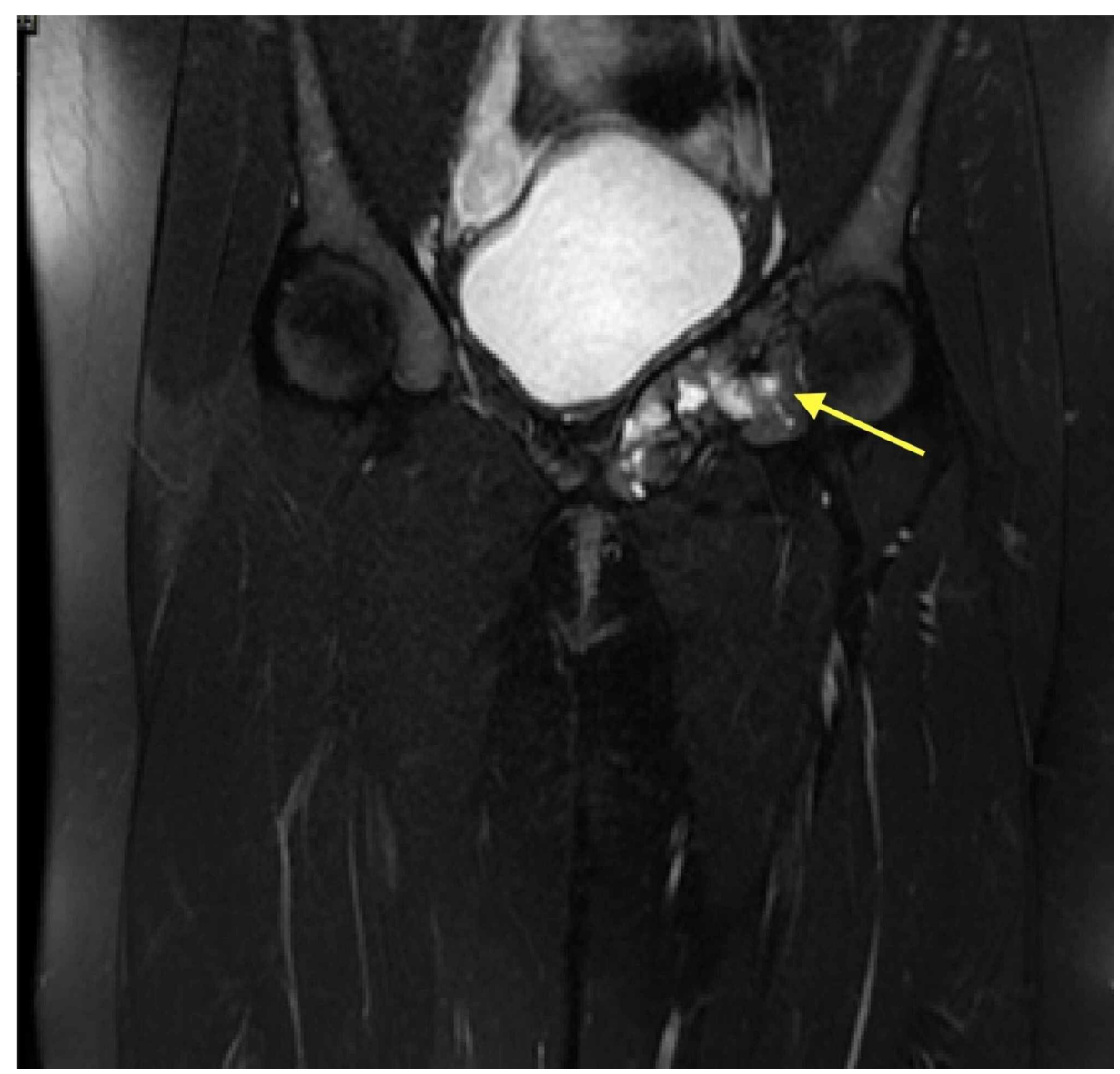

\section{FIGURE 4: T2-weighted magnetic resonance image of the pelvis four years post embolization}

Showed a reduction in size as well as cystic appearance with no new bony lesion.

\section{Discussion}

$\mathrm{ABC}$ is a benign bone lesion with multiple blood-filled cavities. It is highly associated with the destruction of the bone, fractures, and recurrence. It commonly occurs in patients aged <20 years [5]. For instance, our patient was 14 years old upon presentation. Pain is the most presenting symptom and may be associated with limping, restricted motion, and apparent mass.

Diagnosis is usually done by radiography and MRI [6]. In some cases, diagnosis can be missed due to misinterpreted symptoms, including pain that radiating to the medial or the anterior aspect of the thigh and performing knee rather than pelvic radiography [4]. Fluid levels on imaging are the most predictive of ABC.

Differential diagnoses of ABC included unicameral bone cysts, chondromyxoid fibroma, chondroblastoma, giant cell tumor, osteoblastoma, or telangiectatic osteosarcoma. Accurate diagnosis by histology is necessary because the prognosis and treatment of $\mathrm{ABC}$ are entirely different from those of other differential diagnoses [2]. In this case, MRI showed internal septations and the characteristic fluid-fluid levels. The biopsy was done to confirm the diagnosis and exclude other differential diagnoses.

The management of $\mathrm{ABC}$ most commonly consists of curettage and bone grafting, with or without adjuvant therapy. Other treatment modalities have been reported, including en bloc resection, sclerotherapy, radionuclide ablation, and selective arterial embolization. Management of pelvic $\mathrm{ABC}$ is challenging. By considering the patient's age, location, size, vascularity, and degree of invasion of the lesions, the treatment should be carefully chosen.

In the present case, by considering the patient's age, location of $\mathrm{ABC}$, and risk of surgical treatment, the patient was treated by STAE. In most cases of pelvic ABC, STAE is performed preoperatively to decrease intraoperative bleeding for lesions with extensive soft-tissue expansion or lesions greater than $5-8 \mathrm{~cm} \mathrm{[4]}$. Also, it has been reported as a definitive treatment of $A B C[7,8]$. There is no clinically significant difference between the embolic materials. The most important factor that determines the best choice of embolic 
material is operator experience [9]. In our report, PVA particles were used. The maximum number of embolization is seven [10]. Following STAE, the recurrence can occur if the patient's age is under 16 years or the lesion's size is larger than $5 \mathrm{~cm}$, thus embolization can be repeated in these situations. Most of the recurrence occurs within one year of initial embolization [6]. In the present case, only one session was done, as follow-up radiography and MRI showed no new lesion or recurrence, and complete devascularization of an $\mathrm{ABC}$ was achieved. The success rate of embolization for $\mathrm{ABC}$ ranges from $75 \%$ to $94 \%$ with a recurrence rate from $39 \%$ to $44 \%$. Complications included skin necrosis, and temporary paresis can occur in $5 \%$ of patients [8]. However, the application of STAE is limited by lesions with non-identifiable feeding vessels or maybe fed by vessels that supply nearby critical tissues and organs [11].

Other modalities included denosumab therapy and percutaneous treatment with calcitonin and methylprednisolone. Denosumab is a monoclonal antibody targeted against receptor activator of nuclear factor kappa-B ligand (RANKL), its use is dependent on RANK, and RANKL expression was observed histologically in $\mathrm{ABC}$. Ntalos et al. report a case of primary pelvic $\mathrm{ABC}$ in a 35-year-old woman, which was not amenable to surgical intervention [12]. Denosumab led to a significant shrinkage of the lesion. Then, the patient underwent surgical intervention in addition to preoperative STAE. At six months, ABC recurred, which was treated only with denosumab, and a good clinical outcome was observed; however, more cases of pelvic $A B C$ are still needed to further study to conclude its efficacy in the treatment of pelvic ABC [13]. Table 1 shows a summary of the published literature regarding the management of pelvic ABC [1, 4, 14-19].

\begin{tabular}{|c|c|c|c|c|c|c|c|}
\hline Authors & $\begin{array}{l}\text { Number } \\
\text { of } \\
\text { patients }\end{array}$ & Age & Site & Therapy & healed & $\begin{array}{l}\text { Non- } \\
\text { healed }\end{array}$ & Complications \\
\hline $\begin{array}{l}\text { Grahneisa F, et } \\
\text { al. [14] }\end{array}$ & 65 & $\begin{array}{l}4- \\
74\end{array}$ & $23 \%$ pelvis & $\begin{array}{l}\text { Six - resected, five - minimal } \\
\text { invasive, } 54 \text { - curettage }\end{array}$ & 34 & - & $\begin{array}{l}10 \text { - persistence, } \\
12 \text { - recurrence }\end{array}$ \\
\hline $\begin{array}{l}\text { Palmerini E, et } \\
\text { al. [15] }\end{array}$ & 9 & $\begin{array}{l}14- \\
42\end{array}$ & Six - pelvis & Denosumab + surgery & 2 & - & - \\
\hline $\begin{array}{l}\text { Papagelopoulos } \\
\text { P, et al. [4] }\end{array}$ & 40 & $\begin{array}{l}2- \\
44\end{array}$ & $\begin{array}{l}12 \text { - sacrum, seven - } \\
\text { pubis, seven - ischium, } \\
\text { seven - posterior } \\
\text { column, seven - } \\
\text { acetabulum }\end{array}$ & $\begin{array}{l}14 \text { - intralesional curettage, } 21 \text { - } \\
\text { excision curettage }\end{array}$ & 40 & - & $\begin{array}{l}10 \text { - recurrence, } \\
\text { two - tear in the } \\
\text { dura matter, } \\
\text { three - cut of the } \\
\text { lower nerve } \\
\text { roots, two - } \\
\text { deep infections, } \\
\text { one - bowl } \\
\text { obstruction }\end{array}$ \\
\hline $\begin{array}{l}\text { Capanna R, et } \\
\text { al. [16] }\end{array}$ & 23 & $\begin{array}{l}3- \\
45\end{array}$ & $\begin{array}{l}\text { Four - ischium } \\
\text { acetabulum, one - } \\
\text { ischium, two - ileum } \\
\text { acetabulum, one - } \\
\text { ileum, } 13 \text { - ileopub } \\
\text { ram acetabulum + } \\
\text { neck of ileum, one - } \\
\text { hemipelvis, one - } \\
\text { ischiopub ram }\end{array}$ & $\begin{array}{l}\text { Seven - curettage, four - } \\
\text { curettage +homograft, three - } \\
\text { resection, two - biopsy, six - } \\
\text { biopsy + radiation therapy, one } \\
\text { - curettage + radiation therapy }\end{array}$ & - & - & $\begin{array}{l}\text { Three - } \\
\text { recurrence, one } \\
\text { - hypoesthesia, } \\
\text { one - } \\
\text { quadriceps and } \\
\text { psoas deficit, } \\
\text { one - crural } \\
\text { nerve palsy, one } \\
\text { - limb shortened } \\
6.5 \mathrm{~cm} \text {, fem } \\
\text { head necrosis, } \\
\text { one - ankylotic } \\
\text { hip and deep } \\
\text { wound infection }\end{array}$ \\
\hline $\begin{array}{l}\text { Cottalorda J et } \\
\text { al. [1] }\end{array}$ & 15 & $\begin{array}{l}1.5 \\
- \\
15\end{array}$ & $\begin{array}{l}\text { Five - iliopubic ramus, } \\
\text { four - ischiopubic } \\
\text { ramus, two - } \\
\text { acetabulum with } \\
\text { ischiopubic ramus, } \\
\text { two - ilium, one - } \\
\text { acetabulum with } \\
\text { iliopubic ramus }\end{array}$ & $\begin{array}{l}\text { Six - intralesional curettages, } \\
\text { two - intralesional curettages + } \\
\text { bone graft, three - selective } \\
\text { arterial embolization (SAE), one } \\
\text { - preoperative SAE and } \\
\text { curettage, one - curettage and } \\
\text { autogenous bone grafting, two - } \\
\text { biopsies alone }\end{array}$ & - & $\begin{array}{l}\text { One - } \\
\text { large } \\
\text { residual }\end{array}$ & $\begin{array}{l}\text { Two - } \\
\text { recurrence }\end{array}$ \\
\hline \multirow[t]{2}{*}{$\begin{array}{l}\text { Sobeai M, } \\
\text { Juhani W [17] }\end{array}$} & 1 & 24 & Right hip & $\begin{array}{l}\text { Surgical resection after } \\
\text { embolization }\end{array}$ & 1 & - & - \\
\hline & & & \multicolumn{2}{|l|}{ Six - extremities, two - } & & & Two - \\
\hline
\end{tabular}




\section{Cureus}

\begin{tabular}{|c|c|c|c|c|c|c|c|}
\hline $\begin{array}{l}\text { Dubois J, et al. } \\
\text { [18] }\end{array}$ & 17 & $\begin{array}{l}4- \\
15\end{array}$ & $\begin{array}{l}\text { pelvis, two - spine, five } \\
\text { - mandible, one - rib, } \\
\text { one - sphenoid bone }\end{array}$ & Sclerotherapy & 17 & - & $\begin{array}{l}\text { inflammatory } \\
\text { reaction, one - } \\
\text { leakage, one - } \\
\text { small blister }\end{array}$ \\
\hline $\begin{array}{l}\text { Brosjö O, et al. } \\
\text { [19] }\end{array}$ & 38 & $\begin{array}{l}3- \\
26\end{array}$ & $\begin{array}{l}\text { One - pubic bone, two } \\
\text { - sacrum, one - } \\
\text { acetabulum }\end{array}$ & Percutaneous sclerotherapy & 33 & $\begin{array}{l}\text { Two - } \\
\text { residual } \\
\text { pain, two } \\
\text { - follow } \\
\text { up for } \\
\text { symptoms }\end{array}$ & $\begin{array}{l}\text { Three - } \\
\text { inflammatory } \\
\text { reactions, one - } \\
\text { hospital } \\
\text { admission, two - } \\
\text { required } \\
\text { analgesia, one - } \\
\text { moderate } \\
\text { flexion } \\
\text { contracture }\end{array}$ \\
\hline
\end{tabular}

TABLE 1: Published literature

\section{Conclusions}

In treating $A B C$ is essential to exclude other differential diagnoses by biopsy, as the management of $A B C$ is entirely different. As mentioned in the literature review, in some cases, spontaneous healing was documented after a biopsy but most of them have been observed for a long time. Regarding operative management, en bloc resection is out of favor as such aggressive intervention does not appear to be indicated. Curettage and bone grafting is still the main way of management. As there is a risk of introoperative bleeding, STAE before surgery is indicated. Although few cases were reported about the use of STAE as the definitive treatment of pelvic $\mathrm{ABC}$, a good result was achieved in most of these cases. In addition to pre-operative STAE, denosumab has recently been used as a neoadjuvant for surgery and has a reasonable result when used alone to treat the recurrence. Since denosumab can contribute to shrinkage of the tumor, its use with STAE alone has not been reported before. In our case, we treated a primary pelvic $\mathrm{ABC}$ in an adolescent non-surgically by a single session of STAE with an excellent outcome. Even though the management of pelvic $\mathrm{ABC}$ is challenging, good results can be fulfilled with non-surgical treatment if the patient is selected and treated appropriately.

\section{Additional Information \\ Disclosures}

Human subjects: Consent was obtained by all participants in this study. Conflicts of interest: In compliance with the ICMJE uniform disclosure form, all authors declare the following: Payment/services info: All authors have declared that no financial support was received from any organization for the submitted work. Financial relationships: All authors have declared that they have no financial relationships at present or within the previous three years with any organizations that might have an interest in the submitted work. Other relationships: All authors have declared that there are no other relationships or activities that could appear to have influenced the submitted work.

\section{References}

1. Cottalorda J, Chotel F, Kohler R, et al.: Aneurysmal bone cysts of the pelvis in children: a multicenter study and literature review. J Pediatr Orthop. 2005, 25:471-475. 10.1097/01.bpo.0000158002.30800.8f

2. Mankin HJ, Hornicek FJ, Ortiz-Cruz E, Villafuerte J, Gebhardt MC: Aneurysmal bone cyst: a review of 150 patients. J Clin Oncol. 2005, 23:6756-6762. 10.1200/JCO.2005.15.255

3. Timothy B, James P, Michael J: Aneurysmal bone cyst. J Am Acad Orthop Surg. 2012, 20:233-241. 10.5435/JAAOS-20-04-233

4. Papagelopoulos PJ, Choudhury SN, Frassica FJ, Bond JR, Unni KK, Sim FH: Treatment of aneurysmal bone cysts of the pelvis and sacrum. J Bone Joint Surg Am. 2001, 83:1674-1681. 10.2106/00004623-20011100000009

5. Zehetgruber H, Bittner B, Gruber D, et al.: Prevalence of aneurysmal and solitary bone cysts in young patients. Clin Orthop Relat Res. 2005, 439:136-143. 10.1097/01.blo.0000173256.85016.c4

6. Chan G, Arkader A, Kleposki R, Dormans J: Case report: primary aneurysmal bone cyst of the epiphysis . Clin Orthop Relat Res. 2010, 468:1168-1172. 10.1007/s11999-010-1228-5

7. Misasi N, Cigala F, Iaccarino V, Cozzolino F, Sadile F, Marasco E: Selective arterial embolisation in aneurysmal bone cysts. Int Orthop. 1982, 6:123-128. 10.1007/BF00268655

8. Rossi G, Rimondi E, Bartalena T, et al.: Selective arterial embolization of 36 aneurysmal bone cysts of the skeleton with N-2-butyl cyanoacrylate. Skeletal Radiol. 2010, 39:161-167. 10.1007/s00256-009-0757-Z

9. Basile A, Rand T, Lomoschitz F, et al.: Trisacryl gelatin microspheres versus polyvinyl alcohol particles in the preoperative embolization of bone neoplasms. Cardiovasc Intervent Radiol. 2004, 27:495-502. 10.1007/s00270-003-0147-1 


\section{Cureus}

10. Wangqin R, Xu K, Rojas H, Ren Z: Complete resolution of a cervical spine aneurysmal bone cyst after single session of endovascular embolization: case report. Interv Neuroradiol. 2019, 25:330-334.

10.1177/1591019918810534

11. Park H, Yang S, Sheppard W, et al.: Current management of aneurysmal bone cysts . Curr Rev Musculoskelet Med. 2016, 9:435-444. 10.1007/s12178-016-9371-6

12. Ntalos D, Priemel M, Schlickewei C, Thiesen DM, Rueger JM, Spiro AS: Therapeutic management of a substantial pelvic aneurysmatic bone cyst including the off-label use of denosumab in a 35-year-old female patient. Case Rep Orthop. 2017, 2017:9125493. 10.1155/2017/9125493

13. Alhumaid I, Abu-Zaid A: Denosumab therapy in the management of aneurysmal bone cysts: a comprehensive literature review. Cureus. 2019, 11:e3989. 10.7759/cureus.3989

14. Grahneis F, Klein A, Baur-Melnyk A, et al.: Aneurysmal bone cyst: a review of 65 patients . J Bone Oncol. 2019, 18:100255. 10.1016/j.jbo.2019.100255

15. Palmerini E, Ruggieri P, Angelini A, et al.: Denosumab in patients with aneurysmal bone cysts: a case series with preliminary results. Tumori J. 2018, 104:344-351. 10.1177/0300891618784808

16. Capanna R, Bertoni F, Bettelli G, et al.: Aneurysmal bone cysts of the pelvis . Arch Orth Traum Surg. 1986, 105:279-284. 10.1007/BF00449926

17. Sobeai MA, Juhani WA: Pelvic aneurysmal bone cyst: case report and literature review. Int J Surg Case Rep. 2015, 1:20-25.

18. Dubois J, Chigot V, Grimard G, Isler M, Garel L: Sclerotherapy in aneurysmal bone cysts in children: a review of 17 cases. Pediatr Radiol. 2003, 33:365-372. 10.1007/s00247-003-0899-4

19. Brosjö O, Pechon P, Hesla A, Tsagozis P, Bauer H: Sclerotherapy with polidocanol for treatment of aneurysmal bone cysts: good results in 37 of 38 consecutive patients. Acta Orthop. 2013, 84:502-505. $10.3109 / 17453674.2013 .850013$ 